\title{
Equilibrium
}

Quarterly Journal of Economics and Economic Policy

VOLUME 7 ISSUE 2, 2012

ISSN 1689-765X

\author{
Mária Režňáková, Michal Karas* \\ Brno University of Technology, Czech Republic
}

\section{THE EFFECTS OF A CHANGE IN THE ENVIRONMENT ON BUSINESS VALUATION USSING THE INCOME CAPITALIZATION APPROACH}

\section{JEL Classification Codes: $G 32$}

Keywords: strategic analysis, business valuation, sales forecast process

\begin{abstract}
Determining the company value in the conditions of unstable development is a very difficult, almost sophisticated activity. The experience of authors confirms high sensitivity of the resulting company value in relation to critical input parameters, which are known as value drivers. One of these drivers, in case of determining the company value using the income capitalization approach, is the expected sales. In practice, some authors, but mainly experts, limit sales forecast to extrapolation of the identified trend of the past development, while neglecting the importance of the strategic analysis. The aim of the strategic analysis is to identify all factors which may influence future company objectives, i.e. also future sales. This article provides a possible approach to the correction of sales forecast based on the information gained from the strategic analysis.
\end{abstract}

\section{INTRODUCTION}

Determining the value of a company places high demands on valuators and information, because the resulting value of the company itself should reflect all available information about it. The business valuation procedure is very

(C) Copyright Nicolaus Copernicus University Press

Date of Submission: February 15, 2011; date of acceptance: June 4, 2012

* Contact: e-mail: karas@fbm.vutbr.cz, reznakova@fbm.vutbr.cz, Vysoké učení technické v Brně, Fakulta podnikatelská, Kolejní 2906/4, 61200 Brno, Czech Republic 
well described in the literature (Mařík 2007, Kislingerová, 2001). However, some moments occur during the valuation, when the valuator is largely dependent on his own opinion. These moments undoubtedly include the forecast of future income of the business being assessed, the starting point of which is the expected sales. Company sales are a key value driver, which places high demands on an objective assessment of the potential for growth of the company in a competitive environment. The most commonly used approach to sales forecast is their derivation from historical data using the regression analysis. This approach, however, carries a risk of the transmission of deficiencies or short-term company benefits to the future. It is, therefore, necessary that each valuation is preceded by the strategic analysis, which aims at drawing conclusions for sales forecast. If the valuator bases his valuation on past information on the development of company sales, the strategic analysis should serve for him to check whether the historical trend will continue, or whether it will be corrected. The authors assume that a change in the environment (a change in a stock index) will induce a change in sales trends of the company valuated. This fact must be taken into account, if future income-based valuation is to be credible.

The main research method is historical trend extrapolation using regression analysis and a comparison of the results with the conclusions of a strategic analysis of the company's environment. The conclusions thus drawn are then compared with actually achieved values.

The aim of this article is to show a possible way to approach the conclusions of the strategic analysis of sales forecast, which, according to the authors, should lead to higher quality valuations. Sales values actually achieved during the forecast period corroborate the trend change hypothesis.

\section{THEORETICAL BASES OF DETERMINING THE COMPANY VALUE}

In the current economic theory, an opinion prevails that the purpose of making business is the growth of the company value (see e.g. Damodaran 2006; Brigham, Ehrhardt 2008; McKinsey 2005; Mařík et all 2007, 2011; Kislingerová et all 2007; Young, O’Byrne et all 2001). Also in this case a general approach applies that the value is given by a utility value for the owner. In the case of a company, its value derives from the ability to generate future income. Specific determination of the value of a company is then dependent on how the future income of the company is defined and which model (method) of valuation is used. In theory and practice, from the offer of income capitalization approaches, mainly those approaches are used which 
are based on (for more detail refer to Damodaran 2006; Mařík et all 2007, 2011):

- Cash flow - the most widespread method is the method of discounted Free Cash Flow (FCF);

- Economic Value Added (EVA).

Because FCF and EVA are methods drawing predominantly on expected income generated by the company, they seem the most suitable for the demonstration of the effects of a change in the environment on company value calculated using the income approach.

The model of the company value using the discounted free cash flow method is based on the assumption that the value of a company is dependent on the ability to generate future operating cash flow. The generated income is used for reinvestments, which are necessary to maintain sustainable development of the company and pay the owners. The owners who decide what to do with the generated profit will be willing to keep the profits generated in the company for further investments only if the company is able to exploit the available capital more than in other investment opportunities with the same level of risk. The remaining part of the generated operating cash flow (the so-called free cash flow, FCF) can be paid out to company owners. The higher operating cash flow the company generates, the higher potential payment can be paid out to the owners. The required exploitation of the provided capital (equity as well as debt) is reflected in the model at the discount rate.

Free cash flow is defined as operating cash flow minus the investment in the working capital. Free cash flow is then calculated as follows:

$$
F C F_{t}=N O P A T_{t}-\triangle N O A_{t}
$$

where:

$F C F$ - Free Cash Flow generated by the company in year ' $t$ '; $N_{O P A T}$ - Net Operating Profit After Tax; $\triangle N O A_{t}-\triangle$ Net Operating Assets.

Net operating assets are comprised of development investments in net operating fixed assets (fixed assets) and investments in net working capital ( $\triangle N W C$, net working capital). 
The model of the company value using a two-stage method is as follows:

$$
H=\sum_{i=1}^{K} \frac{F C F_{t}}{(1+i)^{t}}+\frac{F C F_{K+1}}{(i-g) \cdot(1+i)^{K}}
$$

where:

$H$ - company value;

$i$ - discount rate;

$K$ - length (number of years) of the first phase of company life;

$g$-expected rate of growth of free cash flow in the second phase of the company life (i.e. from year $\mathrm{K}+1$ to infinity).

The indicator measuring the generation of the company value in a yearly time horizon is the indicator Economic Value Added, which - unlike normally used indicators - reflects the risk rate of achieving income. The basic method of calculating the indicator is as follows:

$$
E V A=N O P A T-W A C C \cdot C
$$

where:

EVA - Economic Value Added;

NOPAT - Net Operating Profit After Tax;

WACC - Weighted Average Costs of Capital;

$C$ - Capital, i.e. financial resources used to finance net operating assets needed to achieve NOPAT.

Capital (C) means paid funding resources, i.e. equity and explicit interestbearing debt resources of funding. In some cases, the reference Net Operating Assets (NOA) is also used, i.e. the capital used to finance net operating assets, which were used to achieve operating profit. Operating profit represents the output of the company achieved from operations, i.e. excluding results from financial, extraordinary or other activities which are not repeatable (i.e. core business).

The cost of capital is the rate of return required by investors and creditors who provided or lent financial sources to the company. The cost of capital depends on the rate of the risk taken by the investor.

The value of the company based on the economic value added, calculated by the two-stage method, is then the sum of capital invested and the present value of future EVAs: 


$$
H=C+\sum_{t=1}^{K} \frac{E V A_{t}}{(1+i)^{t}}+\frac{E V A_{K+1}}{(i-g) \cdot(1+i)^{K}}
$$

As already mentioned, the value of the company depends on its ability to generate future income. This means that it depends on the uniqueness and quality of the product offered, which influence the demand for the product, on the position of the company in the market, on the level of effective cost management, on innovative abilities of company employees, on the ability to seek new investment opportunities and effectively utilize available recourses, i.e. to manage the processes and activities in the company. These principles are contained in the concept of value based management. One of the principles of this concept is the use of new indicators, which are more accurate in measuring the effectiveness of processes and elements (entities), by which the value is driven. This gave rise for their designation: value drivers. The crucial value drivers are (Damodaran 2006):

- sales, which constitute the main item of operating income;

- operating margin, which depends on the cost structure and management;

- amount of capital invested in fixed assets, efficient use of these assets and the way of managing net working capital;

- rate of and return on investment, which are reflected in the ownership structure of the company and substantially affect the financing structure;

- cost of capital, which depends on the structure of financing, risk-free rate of return and premium for the risk taken by the owner or creditor.

In the following section, we will focus on the importance of specifying sales for the objective determination of company value. Their specification is the result of the company strategic analysis.

\section{STRATEGIC ANALYSIS}

In literature, the concept of the strategic analysis appears in two prima facie different meanings, which, however, complement one another.

The first view is represented by strategic management. (Sedláčková 2006, p. 10) defines the strategic analysis as a process whose aim is to identify, analyse and evaluate all relative factors which may be expected to affect the final choice of objectives and business strategies. The strategy (e.g. Koontz, Weihrich 1993 p. 123) is defined as the determination of long-term fundamental business objectives and definition of necessary activities and resources to achieve these objectives. The goal of the company then represents desirable statuses, which the company seeks to achieve through its existence 
and activities (Keřkovský, Vykypěl 2003 p. 10). This consideration must be based on an analysis of the company surroundings. The effect of the surroundings on the company is usually very strong, while the ability of the company to influence the surroundings is rather limited (Synek 2002).

According to Jauch and Glueck (in: Keřkovský, Vykypěl 2003, p. 37), the company surroundings can be divided to:

- General surroundings, which include the socio-economic sector, technology sector and government sector. In terms of valuation, it is necessary to focus particularly on the analysis of economic factors (stage of the economic cycle, monetary and fiscal policy, inflation rate, the situation on the capital market, etc.).

- Industry surroundings, which consist of customers, suppliers and competitors. To analyse the company's industry surroundings, the so-called Porter Model can be used (Porter 1994, pp. 3-22).

The said factors of the company surroundings should be supplemented with the analysis of the internal company environment, which consists of technical development factors, marketing, distribution channels, production factors, human resources, as well as financial and budgetary factors. At this level, the strategic analysis serves to explain the company objectives and strategy.

The second, divergent view can be found in business valuation issues. Business valuation methods are divided (see e.g. Mařík et all 2007) primarily to methods based on the proprietary principle and methods based on the income capitalization principle. While proprietary methods are based primarily on historical data, income capitalization methods are mainly based on future, predicted values. This collection of information takes the form of the strategic and financial analysis, which leads to the compiling of a financial plan on the basis of which valuation is performed. The function of the strategic analysis for business valuation is to determine the overall income potential of the company valued (see e.g. Mařík et all 2007). In this case, the author uses the designation of internal and external potential.

External potential collectively expresses opportunities and risks offered by the business environment (industry, relevant market), in which the company valued acts.

Internal potential means the ability of the company to make use of the opportunities of the external environment and to face its risks. A concentrated expression of the internal potential is a summary of its main strengths and weaknesses, with emphasis on the question whether the company has a significant competitive advantage(s) or not. An important part of the internal potential analysis is the competition of the company valued. 
For the strategic analysis, the following procedure is defined:

- Defining the relevant market, its analysis and forecast (analysis of the external potential).

- Analysis of competition and company's internal potential.

- Forecast of sales of the valued company, which is the result of the previous two steps.

In this concept, the strategic analysis is used to evaluate opportunities and risks with regard to achieving the planned income in the future. Its output is a financial plant. Undoubtedly the most difficult step is the preparation of sales forecast. The quality of the forecast is crucial to the quality of the financial plan and company valuation. In this article, the strategic analysis is perceived in this sense. The status and progress of the strategic analysis is presented below (Figure 1).

Figure 1. Strategic analysis in determining the value of the company

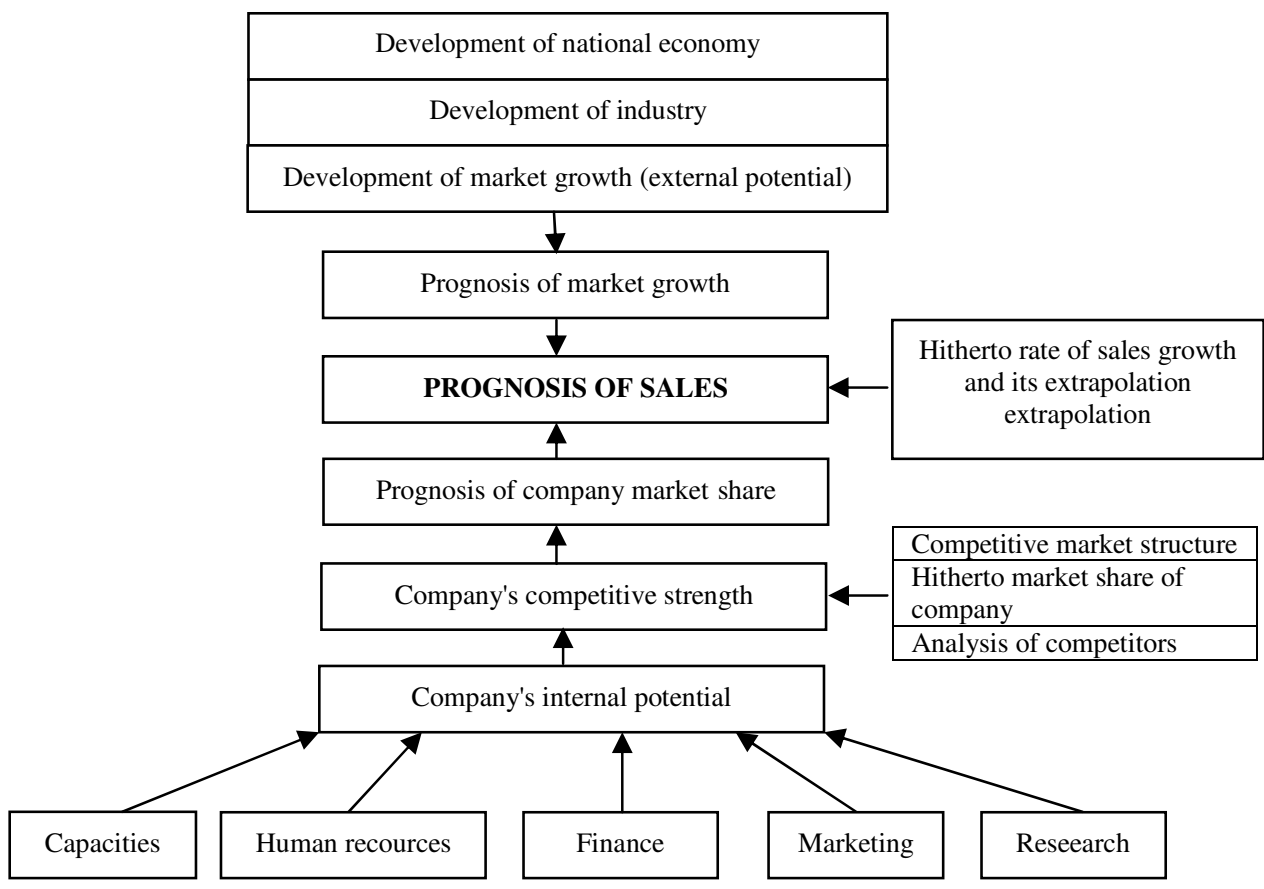

Source: Mařík et all (2007), processed by the author. 
The financial plan is one of the most important and in terms of the difficulty of preparation one of the most complicated partial plans of the company. This follows from the fact that the financial plan is a qualitative statement of all business activities focused on operations and business growth. It has an integrating position in the system of business plans because all partial plans of the company merge in it. The financial plan does not only have a passive role of summarizing outcomes of the partial plans, but actively influences them and, consequently, the entire reproductive process of the company. It fulfils this role by determining the available financial resources for financing business activities. To compile partial components of the plan, the method of the percentage share in sales can be then used. (On this topic, see e.g. Koráb, Režňáková, Petrenka 2007, pp. 127-203).

\section{Approaches to company sales forecasting}

To determine the sales, three basic approaches can be identified (see e.g. Kislingerová, 2001, p. 203) on the basis of:

- analysis of historical data,

- analysis of company internal potential,

- qualified opinion of analysts regarding the development of the company, industry and economy as a whole.

In order to determine the sales on the basis of historical data, the author recommends using a 3-5-years-long time series as a basis, which leads to the derivation of the rate of sales growth. To do this, you can use the following methods (Hindls et all 2006):

- Average historical values. To determine the rate of sales growth, geometric average is most commonly used, which better reflects the principle of prudence in estimating the future development of the company the valuator must comply with.

- Time series models. The traditional approach is a one-dimensional model $y_{t}=f\left(t, \varepsilon_{t}\right)$, where $y_{t}$ is the value of the modelled indicator at time $t, t=$ $1,2, \ldots, n$.

$\varepsilon_{t}$ is the value of a random component (interference) at time $t$.

- Models of regression analysis. The task of the regression analysis is a mathematical description of systematic circumstances that accompany statistical dependencies. This mathematical description has the form of a regression function. The aim of the regression analysis is the best possible approximation of the values calculated on the basis of the regression function to the hypothetical regression function.

- Box-Jenkins models. Compared to conventional models, it deals with the modelling of a random component; a serious of random components $\varepsilon_{t}$ then forms the so-called white noise. The precondition for using this 
method is the existence of a time series of data longer by at least $40-50$ observations.

Using historical data is a fundamental approach to forecast future values. When using this approach, it is necessary to take into account particularly the following factors (Kislingerová 2001, p. 204):

- Variability of business growth rates. With the increasing variability of values in time, uncertainty is growing regarding the estimate of the future. The degree of this uncertainty can be expressed as a standard deviation.

- Quality of income achieved. This is essentially the identification of oneoff and short-acting effects, which temporarily destabilized the development of the company. They can have a form, for example, of extraordinary income and extraordinary expenses, or the income from the sale of materials or fixed assets.

- Sensitivity of the company to changes in economic business cycle. To generalize the results of the past, it is necessary to monitor the rate of sales growth for at least two business cycles.

- The size of the company and the stage of its life cycle. At the beginning of its life cycle, the company grows, then it stabilizes, and then it declines (as measured by sales growth).

- Major changes in strategic management. These may include, for example, consequences of changing the ownership structure or of the macroeconomic environment.

Attention should also be given to some other factors, such as the segmentation and potential of niche of the market.

Damodaran (2002) points out the threats associated with the projection of historical trends into the future. He mentions a study by Little (Little 1962), who maintains that the fact that a company achieved growth in the past does not necessarily mean that a similar growth can also be expected in the future. The authors of some other studies go as far as to assert that accurate forecasts are not possible (Makridakis, Taleb 2009) for the following reasons:

- History never repeats itself in exactly the same way (see statistical forecasting models based on an extrapolation of a past trend).

- Statistical models assume independence of individual events, which, at the time of globalization and interconnection of world markets, is a very unrealistic assumption that may at times lead to a catastrophic underestimation of uncertainty.

In determining the sales on the basis of internal parameters of the business functioning, there are two possible approaches, based on the determination of:

- Internal rate of business growth, established on the basis of return on equity and activation ratio. 
- Sustainable rates of company growth, determined on the basis of return on equity and company capital structure.

It is clear that each valuator will analyze the company on the basis of past data, and use this data in greater or lesser extent to determine the sales forecast. Of the said approaches, the regression analysis can be recommended. The question remains of the construction of an appropriate model.

First, it is necessary to focus on the choice of an explanatory variable. As Mařík states (2007, pp. 468-469), in a quality model there should be relatively strong interdependence between the explanatory and explained variable in one equation (the correlation coefficient approximately above $75 \%$ ). And by contrast, the interdependence between explanatory variables in one equation should be insignificant. The strength of interdependence can be measured by the correlation coefficient, either by the classical (Pearson) correlation coefficient or by the ordinal (Spearmann) correlation coefficient.

According to Mařík (2007, pp. 469-470), the quality of a model can be then measured by the index of determination, tests of regression models (partial $t$-tests of individual models, overall $F$-test of the model), or by predictive tests which are used to test the forecasting capabilities of explanatory variables. In this case, from the past time series, the same number of years is selected, for which there is a need to compile a forecast. The forecasted values are then calculated. The deviation of actual and forecasted values is measured e.g. by percentage, Thail index, etc.

\section{RESULTS}

The above approaches will be presented on the case of the valuation of a company dealing with repair, installation and maintenance of industrial facilities. This company is a medium-sized enterprise with a legal form of a private joint-stock company. Two methods were used for the valuation: the method of discounted free cash flow (the entity version) and the method of economic value added.

\section{Estimated rate of sales growth}

The rate of sales growth of the company valued was derived from the market sales growth rate and expected inflation ${ }^{1}$. Market development is forecasted on the basis of the estimates of gross domestic product (GDP) prepared by the Ministry of Finance of the Czech Republic. A logarithmic regression function was used for this, which proved most suitable on the

\footnotetext{
${ }^{1}$ In this case as: Company sales growth rate $=($ market growth rate + inflation rate $) / 2$.
} 
basis of a test of forecasting capabilities. The estimated sales growth rate of the company was then determined as the arithmetic average of the market growth rate and forecasted inflation. This procedure was used to forecast the sales for the period 2008-2012.

Table 1. Test of forecasting capabilities

\begin{tabular}{|l|c|c|c|c|}
\hline \multicolumn{2}{|c|}{ Position } & $\mathbf{2 0 0 6}$ & $\mathbf{2 0 0 7}$ & $\mathbf{2 0 0 8}$ \\
\hline \multirow{2}{*}{ X (GDP) } & \multirow{2}{*}{ Actual } & $\begin{array}{c}\mathbf{3 2 2 2 . 0} \\
\mathbf{0}\end{array}$ & $\mathbf{3 5 3 5 . 0 0}$ & $\mathbf{3 6 9 6 . 0 0}$ \\
\cline { 1 - 4 } Y (market) & & $\mathbf{2 4 7 . 3 8}$ & $\mathbf{2 9 4 . 2 8}$ & $\mathbf{2 9 4 . 4 2}$ \\
\hline \multirow{3}{*}{} & Linear & 250.70 & 283.91 & 300.99 \\
\cline { 2 - 5 } & $\begin{array}{c}\text { Logarith- } \\
\text { mic }\end{array}$ & 250.48 & 284.55 & 300.91 \\
\cline { 2 - 5 } & $\begin{array}{c}\text { Polynomi- } \\
\text { al }\end{array}$ & 395.83 & 472.96 & 489.73 \\
\hline
\end{tabular}

\begin{tabular}{|c|c|c|c|c|c|}
\hline Position & $\mathbf{2 0 0 6}$ & $\mathbf{2 0 0 7}$ & $\mathbf{2 0 0 8}$ & Suma & Max \\
\hline Actual & $\mathbf{2 4 7 . 3 8}$ & $\begin{array}{c}\mathbf{2 9 4} \\
\mathbf{2 8}\end{array}$ & $\mathbf{2 9 4 . 4 2}$ & & \\
\hline Linear & $1.341 \%$ & $\begin{array}{c}3.52 \\
5 \%\end{array}$ & $2.231 \%$ & $\begin{array}{l}7.097 \\
\%\end{array}$ & $\begin{array}{l}3.525 \\
\%\end{array}$ \\
\hline $\begin{array}{c}\text { Loga- } \\
\text { rithmic }\end{array}$ & $\mathbf{1 . 2 5 1 \%}$ & $\begin{array}{c}\mathbf{3 . 3 0} \\
\mathbf{7 \%}\end{array}$ & $\mathbf{2 . 2 0 6 \%}$ & $\begin{array}{l}\mathbf{6 . 7 6 5} \\
\mathbf{\%}\end{array}$ & $\begin{array}{l}3.307 \\
\%\end{array}$ \\
\hline $\begin{array}{c}\text { Polyno- } \\
\text { mial }\end{array}$ & $\begin{array}{c}60.010 \\
\%\end{array}$ & $\begin{array}{c}60.7 \\
16 \%\end{array}$ & $66.338 \%$ & $\begin{array}{c}187.0 \\
63 \%\end{array}$ & $\begin{array}{l}66.33 \\
8 \%\end{array}$ \\
\hline
\end{tabular}

Source: Mařík et all (2007), processed by the author.

In the next step, the strategic analysis of the company was performed. The analysis suggested the following conclusions:

Figure 2. SWOT analysis of the company valued

\begin{tabular}{|l|}
\hline \multicolumn{1}{|c|}{ Strengths } \\
\hline quality of services rendered \\
\hline low indebtedness \\
\hline positive net working capital \\
\hline
\end{tabular}

\begin{tabular}{|l|}
\hline \multicolumn{1}{|c|}{ Weaknesses } \\
\hline $\begin{array}{l}\text { low operating cash flow, does not give } \\
\text { sufficient resources for development }\end{array}$ \\
\hline $\begin{array}{l}\text { low profitability - excessive involvement of } \\
\text { company's own resources }\end{array}$ \\
\hline
\end{tabular}


Figure 2 Continued

\begin{tabular}{|l|}
\hline \multicolumn{1}{|c|}{ Strengths } \\
\hline $\begin{array}{l}\text { flexible organizational structure - strate- } \\
\text { gic business units (SBU) }\end{array}$ \\
\hline $\begin{array}{l}\text { customers are large companies and com- } \\
\text { panies with strong capital }\end{array}$ \\
\hline good name, company name \\
\hline low depreciation of fixed assets \\
\hline $\begin{array}{l}\text { ownership of certificates ISO 9001 and } \\
\text { ISO 14001 }\end{array}$ \\
\hline strong marketing \\
\hline \multicolumn{1}{c|}{ Opportunities } \\
\hline new technologies, patents and know-how \\
\hline growing market \\
\hline weaker bargaining position of suppliers \\
\hline introduction of new services \\
\hline focus on foreign markets \\
\hline acquiring new customers \\
\hline
\end{tabular}

\begin{tabular}{|l|}
\hline \multicolumn{1}{|c|}{ Weaknesses } \\
\hline $\begin{array}{l}\text { high dependency on a few key customers (6 } \\
\text { companies account for } 72 \% \text { of total perfor- } \\
\text { mance) }\end{array}$ \\
\hline very low levels of liquidity \\
\hline $\begin{array}{l}\text { increasing values of time of short-term } \\
\text { receivables collection }\end{array}$ \\
\hline $\begin{array}{l}\text { productivity of work from sales (or value } \\
\text { added) under the industry average }\end{array}$ \\
\hline \\
\hline $\begin{array}{l}\text { Threats } \\
\text { trial production }\end{array}$ \\
\hline lower customer investment activity \\
\hline $\begin{array}{l}\text { expected decline in exports and imports } \\
\text { of goods and services }\end{array}$ \\
\hline $\begin{array}{l}\text { long period of maturity of short-term re- } \\
\text { ceivables }\end{array}$ \\
\hline many competitors with strong capital \\
\hline possible loss of strategic customer \\
\hline
\end{tabular}

Source: Mařík et all (2007), processed by the author.

\section{Motivation to modify sales forecast}

The company has enough strengths, which is demonstrated by its historical development. However, the analysis of the external surroundings shows threats, the consequences of which may change the trend in which the sales of the company develop. The validity of these concerns as at the date of valuation is documented by the following graph (Figure 3), which shows the evolution of the Dow-Jones index ${ }^{2}$. The vertical dashed line represents the date of valuation. Given that the values of stock prices are a few months

${ }^{2}$ The main index of the Czech economy is index PX; but with regard to a lower number of titles contained, we consider its informative value as lower. 
ahead of the economic development and become an indicator of further economic development, the consideration of the need to correct the historical development of sales is justified.

Figure 3. Evolution of Dow-Jones index in 2006-2011

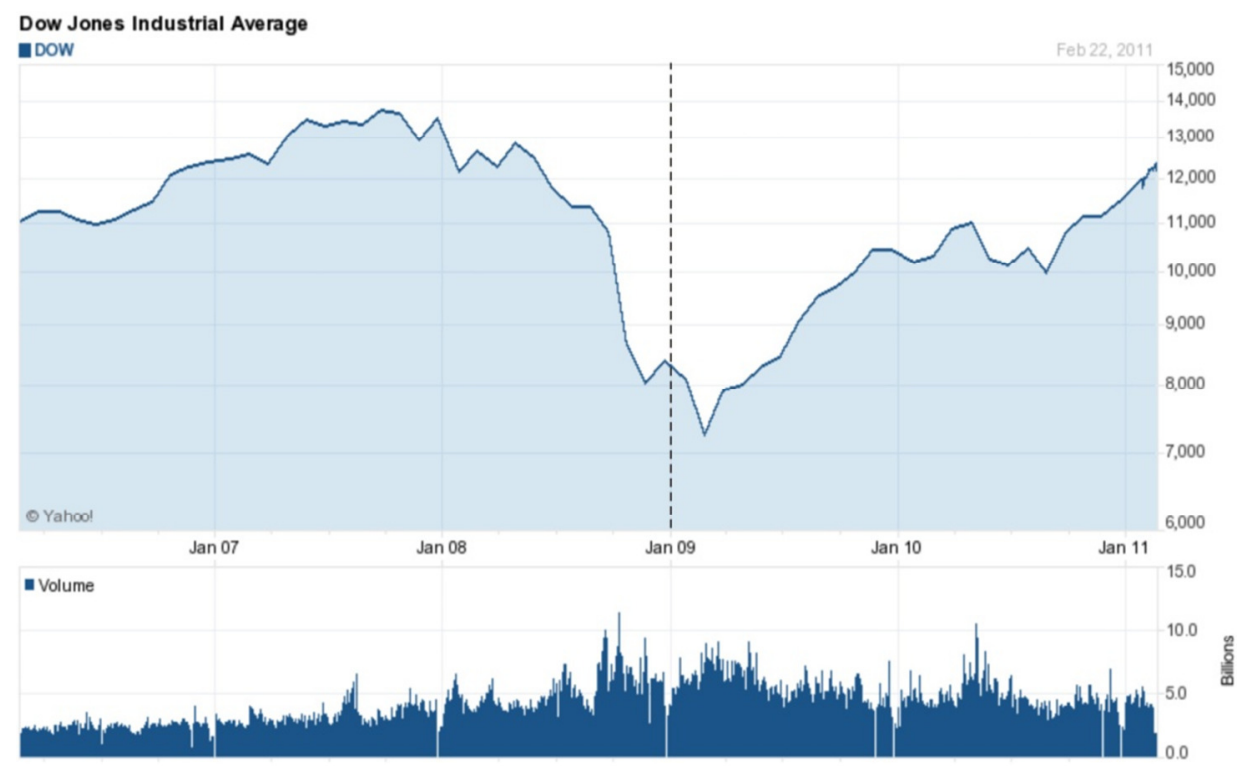

Source: Yahoo.finance.com.

The danger of such a situation is highlighted by Copeland (Copeland et all 1991, pp. 219-220). He warns against too pessimistic or too optimistic expectations. In the case of cyclical industries ${ }^{3}$ the estimation of a permanent value $^{4}$ is particularly sensitive to the phase of the cycle on which the estimates are based. Problems may occur when the end of the forecasted period falls elsewhere than in an average year. The author proposes to move the forecasted period to an average year ${ }^{5}$.

${ }^{3}$ The industry in which the company valued operates can be definitely described as cyclical. This can be demonstrated e.g. by the value of Pearson correlation coefficient. Its value is 0.99250 for the correlation between the development of GDP and development of sales in the market in which the company operates, or 0.77989 for the correlation between the development of company sales and development of the market sales.

${ }^{4}$ In more recent literature, this value is more often mentioned as the value of the second phase. It is a value of the stream of expected company income after an explicitly forecasted period.

${ }^{5}$ A year which does not immediately precede the peak or saddle of the economic cycle. 
In practice, this condition is difficult to meet. Complications occur mainly in the sales forecast for long terms. Especially in conditions of uncertainty that prevailed at the time of valuation, the sales forecast can be made with reasonable reliability only for a few years ahead.

\section{Sales development of the company valued}

The following graph (Graph 1) shows the historical development of company sales for the period 2002-2008. The graph is not showing absolute values of sales, but their basic index as at 2002. In 2008, the company achieved its greatest growth in sales for the entire period monitored. From the graph, it is clear that after every period, which saw an increase, a decline followed. It is, therefore, legitimate to assume that the first year of forecast (i.e. 2009) will begin with a decline. The legitimacy of this concern is supported also by the variability of the historical sales development ${ }^{6}$. The average value of sales for the period 2001-2008 amounts to CZK 107,170 thousand, the standard deviation was CZK 32,440 thousand.

Graph 1. Basic index of sales development in the period 2002-2008

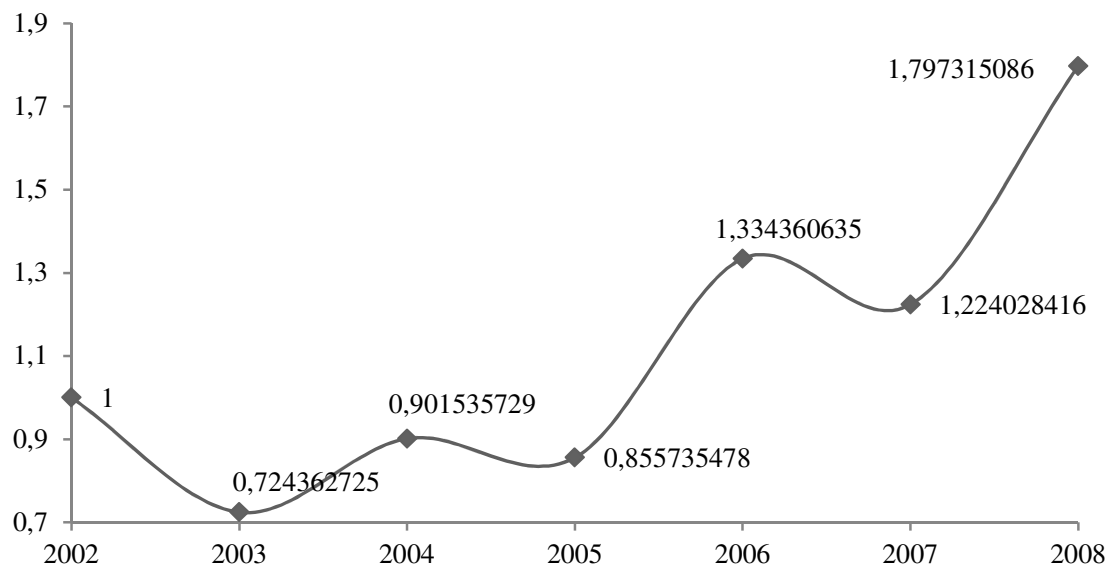

Source: financial statements of the company valued, processed by the author.

\footnotetext{
${ }^{6}$ Variability of sales represents a significant risk of error for the methods of sales forecasting based on historical data. Using the models of variability, which are used to forecast stock prices, was not possible due to the low number of observations.
} 


\section{Sales forecast of the company valued}

The following graph (Graph 2) shows the values of sales complemented by the forecast made using the logarithmic regression function. Although it is not entirely clear from the graph, year 2009 expects the sales to rise (by about $1.63 \%$ ).

Graph 2. Optimistic sales forecast 1

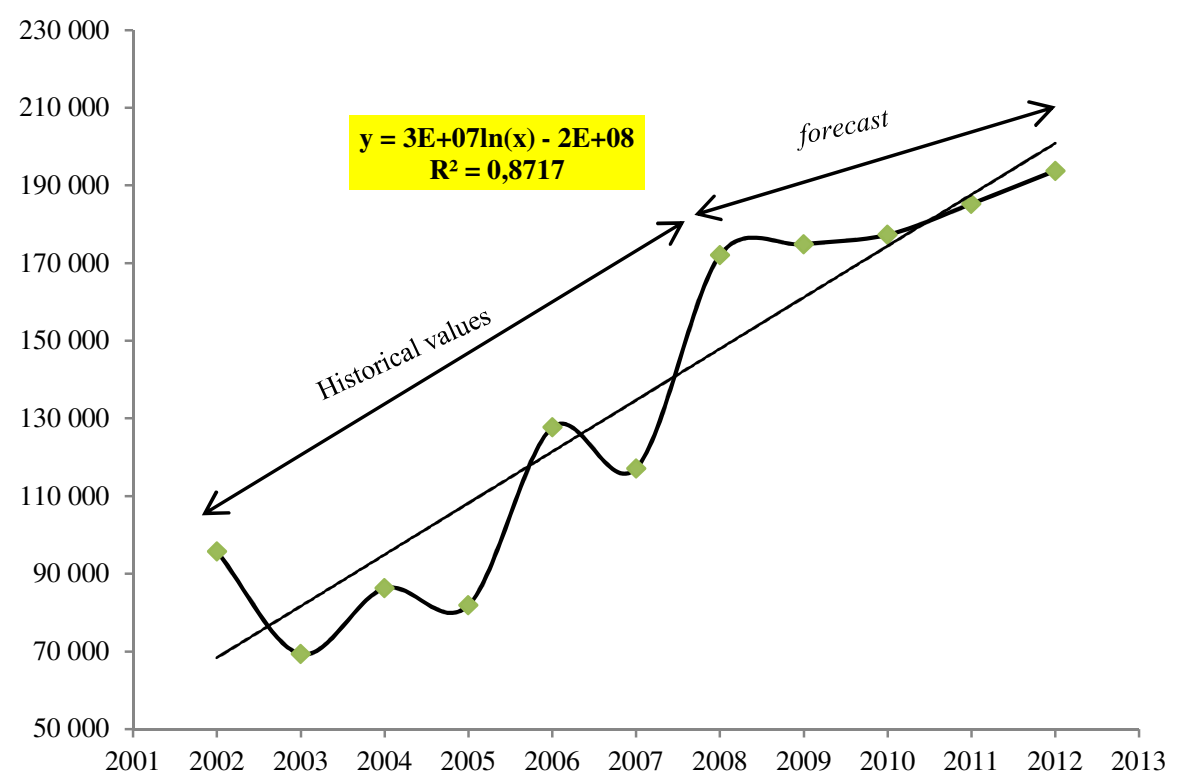

Source: financial statements of the company valued, processed by the author.

The strategic analysis also pointed out that with high probability sales will decline in 2009. It was therefore necessary to take this fact into account in the forecast. The revised sales forecast was prepared in two versions: in the optimistic version (Graph 2) and in the pessimistic version (Graph 3). The optimistic version respects the extreme growth in 2008, the pessimistic leaves it out ${ }^{7}$. Both graphs are interspersed with a logarithmic trend ${ }^{8}$. Obviously, the correlation coefficient for the pessimistic version is much lower. The reason is the correction of past data by excluding the extreme value of 2008.

\footnotetext{
${ }^{8}$ This is, however, the dependence of sales on time, which is different from the dependence on the basis of which sales are forecasted.
} 
Graph 3. Pessimistic version of sales forecast 1

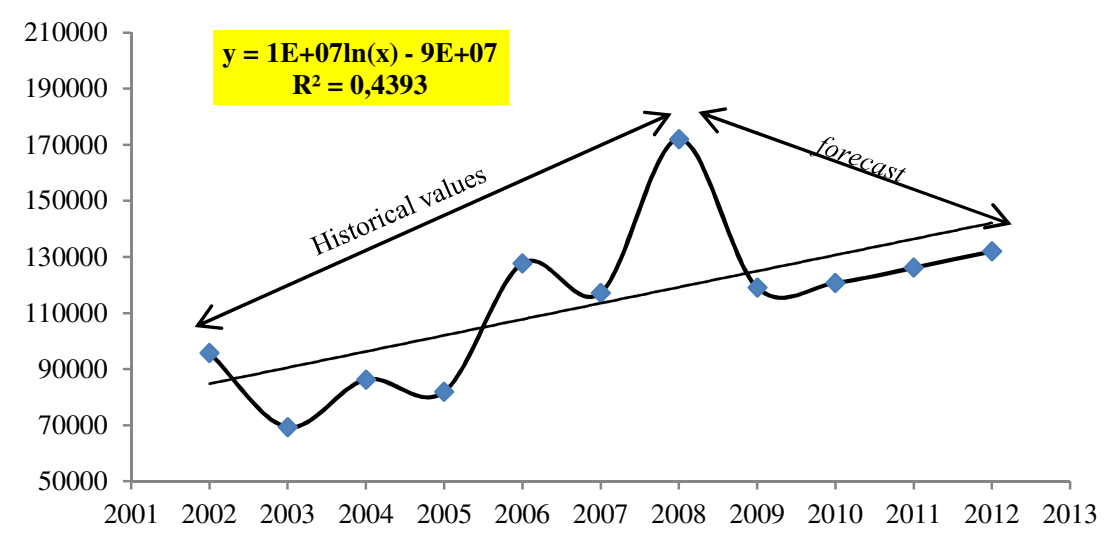

Source: financial statements of the company valued, processed by the author.

The average annual rate of company sales growth during 2002-2008 as measured by the geometric average, which is not as sensitive to extreme values as the arithmetic average, is $10.26 \%$; the average rate of sale growth for the forecasted period is $3.02 \%$.

The strategic analysis did forecast a decrease in sales in 2009, but there was no indication for such a low value. The correction of the estimated future development to the value $6.58 \%$ was thus made. The following graph (Graph 4) then shows a modified optimistic version. The mentioned modification led to the higher correlation coefficient.

Graph 4. Optimistic version of sales forecast 2

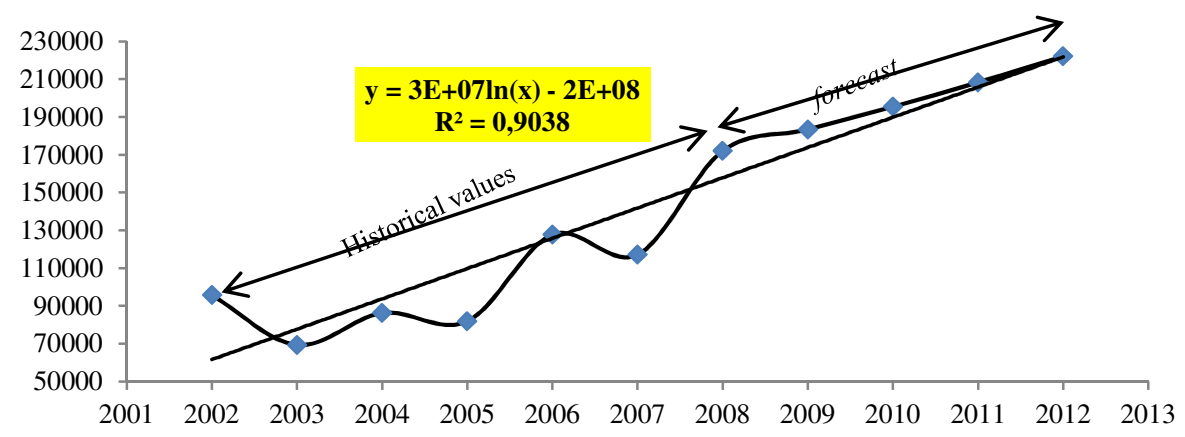

Source: financial statements of the company valued, processed by the author. 
A similar modification was made also for a pessimistic version/variant. This modification resulted in a significant increase in the correlation coefficient.

Graph 5. Pessimistic version of sales forecast 2

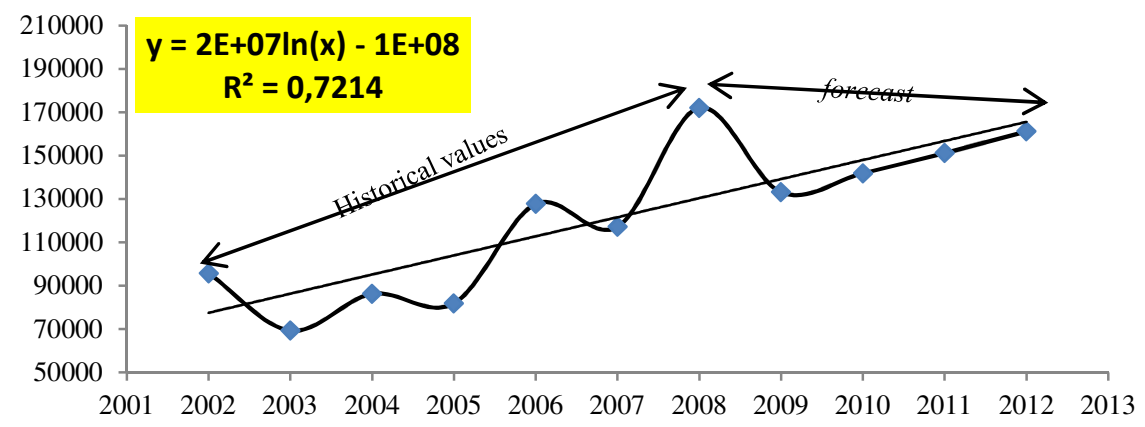

Source: financial statements of the company valued, processed by the author.

The company's actual sales over the forecast period

In due time, we obtained the data on the company's actual sales in 2009 and $2010^{9}$. A comparison of the actual to the originally forecast values allows us to assess the veracity of the working hypothesis on trend change.

Graph 6. Comparison of actual to forecast sales figures

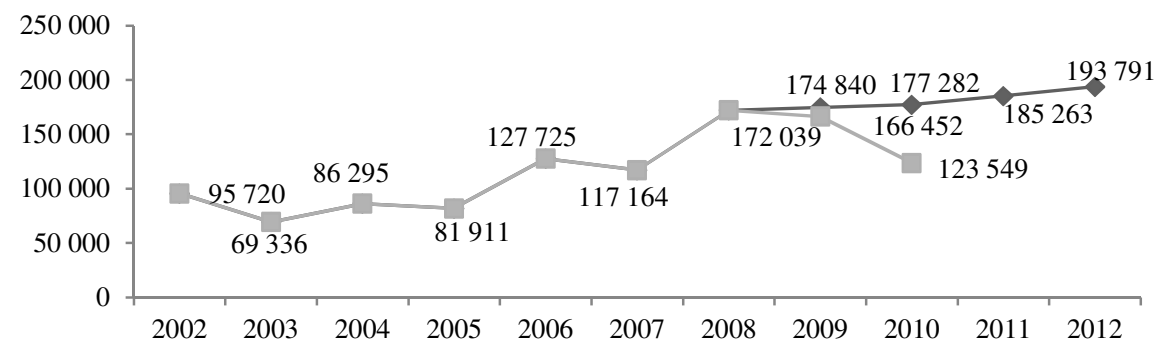

Source: financial statements of the company valued, processed by the author.

\footnotetext{
${ }^{9}$ The company merged with another company in 2011.
} 
Consequences of correction for determining the value of the company

The effect of sales forecast correction to a quantified company value is shown in the following table (Table 2).

The results show a large spread between the resulting company value in case of a pessimistic and optimistic version set on the basis of uncorrected data is much higher than in the case of corrected data. It can be, therefore, regarded as more correct. How to correct the sales, however, is still to be discussed.

Table 2. Company quantified value in thousand CZK

\begin{tabular}{|c|r|r|r|r|}
\hline \multirow{2}{*}{$\begin{array}{c}\text { Resulting } \\
\text { value }\end{array}$} & \multicolumn{2}{|c|}{ Non-modified version } & \multicolumn{2}{c|}{ Modified version } \\
\cline { 2 - 5 } & optimistic & pessimistic & \multicolumn{1}{c|}{ optimistic } & \multicolumn{1}{c|}{ pessimistic } \\
\hline DCF method & 53946 & 27718 & 68834 & 44597 \\
\hline EVA method & 60763 & 28280 & 76385 & 45972 \\
\hline
\end{tabular}

Source: processed by the author.

\section{CONCLUSIONS}

The aim of the article was to highlight the frequently overlooked feedback between the strategic analysis and the sales forecasting process and outline a possible procedure of sales forecast correction in line with the conclusions of the strategic analysis. The procedure was presented on a case of valuating a concrete business in the Czech Republic. Within this process, the effect of changes in sales forecast on the company value was investigated under the assumption of otherwise relatively unchanged conditions. Compared to a conventional procedure, the procedure presented is different by the fact that it introduced two versions of sales forecast. Given the uncertainty of the future development of the environment, the continuation of the previous trend cannot be reliably expected. The introduction of the second version is the expression of the principle of prudence in valuation. The addition of the pessimistic version ultimately leads to a lower value than would be achieved without it. This difference can then represent the value by which the company is overvalued.

This conclusion is corroborated by the actual values recorded in 2009 and 2010. A valuation based on the original trend would undoubtedly be a distorted one. The conditions under which this conclusion can be generalized for other companies are results of further research. 
There will undoubtedly be more procedures on how to construct a second version of sales; the presented method reflected the specific situation which occurred in the company valued in the last year. In conclusion, it is necessary to note that the sales forecast prepared in this way should sufficiently reflect the risk of environment changes, so the discount rate should no longer include risk premiums.

\section{LITERATURE}

Brigham E.R., Ehrhardt M.C. (2008), Financial Management. Theory and Practice, South-Western.

Damodaran A. (2006), Damodaran on Valuation: Security Analysis for Investment and Corporate Finance, John Willey \& Sons, New York.

Damodaran A. (2002) Investment valuation: tools and techniques for determining the value of any asset, John Willey \& Sons, New York.

Copeland T., Koller T. Murrin J. (1991), Stanovení hodnoty firem., Victoria Publishing, Praha.

Hindls R., et all (2006), Statistika pro ekonomy, Professional Publishing, Praha.

Keřkovský M., Vykypěl O. (2006), Strategické ř́zení: teorie pro praxi, C.H.Beck, Praha.

Kislingerová E. (2001), Oceňování podniku, C.H.Beck, Praha.

Koontz H., Weihrich, H. (1993), Management, Victoria Publishing, Praha.

Little I.M.D. (1962), Higgledy Piggledy Growth, Institute of Statistics, Oxford.

Makridakis S., Taleb N. (2009), Living in a world of low levels of predictability. International Journal of Forecasting, Vol. 25, No. 4.

Mařík M. (2007), Metody oceňování podniku: Proces ocenění základní metody a postupy, Ekopress, Praha.

Mařík M. (2011), Metody oceňování podniku pro pokročilé: Hlubší pohled na vybrané problémy, Ekopress, Praha.

Ministerstvo financí České republiky (2009) Makroekonomická predikce České republiky, http://www.mfcr.cz/cps/rde/xchg/mfcr/xsl/makro_pre.html (1.9.2009).

Porter M.E. (1994), Konkurenční výhoda, Victoria Publishing, Praha.

Sedláčková H., Buchta K. (2006), Strategická analýza, C.H.Beck, Praha.

Synek M. (2002), Podniková ekonomika, C.H.Beck, Praha. 
